\section{Sophisticated astronomy}

\section{Euan W. MacKie}

Megaliths and Masterminds. By $\mathrm{P}$. Lancaster Brown. Pp. 246. (Robert Hale: London; Scribners: New York 1979.) £5.50; $\$ 14.95$.

THE title suggests that here is another attempt to capitalise on the increasing interest, at many levels, in the evidence for sophisticated astronomical practices in the monuments of Neolithic and Early Bronze Age Europe. There must be at least a dozen books on the market at present with similar titles, and each with a picture of Stonehenge or some other megalithic site on the jacket, so the reviewer may be forgiven for having become somewhat hard to please in this area. These books vary considerably in quality, from the frankly mystical, through orthodox archaeological textbooks to excellent explanations of a difficult and complex subject (see Nature, 275, 75; 1978). One may well ask, what is the purpose of another one unless it includes original research or new ideas?

$\mathrm{Mr}$ Lancaster Brown in fact ranges more widely than the megaliths of the title, which he correctly defines as including both the standing stone sites of Britain and Brittany and the chambered burial mounds of Atlantic Europe from Spain to Scandinavia (although the latter also include drywalled constructions and, if the collective burial rite is thought to be the decisive linking feature, some rock-cut tombs as well, which are in no sense megalithic). He has chapters on almost everything connected with astronomy in the ancient world, starting with Alexander Marshack's 'lunar notation' scratches on Palaeolithic bone implements. However, his suggestion that these marks, dating to well before 12,000 years ago, may be ancestral to the Irish Ogham script of less than 2,000 years ago will scarcely find favour with philologists and simply shows that speculating in the historical disciplines can seem too easy to the layman.

The author is, however, very interesting on the early development of research into archaeoastronomy and

- In the review of Physical Chemistry: Principles and Applications for the Biological Sciences by Tinoco, Sauer and Wang, (Nature, 278, 85; 1979), it was incorrectly stated that a paperback edition had been published. A hardback edition only is available from PrenticeHall International at £12.95, with a paperback Solutions Manual at $£ 2.55$. ancient metrology, and this is perhaps the most useful part of the book. We are given vivid accounts of Sir Norman Lockyer, L. Piazzi Smyth and Sir Flinders Petrie at work among the temples, pyramids and obelisks of ancient Egypt and of the evolution of thought about astronomical qualities in British prehistoric sites from the seventeenth century onwards. It is very useful to be reminded that many of the modern ideas about ancient astronomy and metrology, developed in such detail by the Thoms, in fact derive from those of earlier workers, and salutory to learn again that some of these became obsessed with their theories to such an extent that they ignored or derided the histonical and archaeological evidence. It is true that archaeologists were often of little help, usually being innately sceptical about archaeoastronomical ideas, but they were sometimes faced with such amazing nonsense that their scepticism is understandable.

The author provides one classic example from Lockyer's 1909 book on Stonehenge in which he discussed the living quarters of the astronomerpriests who, he assumed, were at work in Neolithic Britain. He supposed that damp was a severe problem so that shelters were needed, but assumed quite arbitrarily that the people of 4,000 years ago were entirely ignorant of carpentry. Thus they had to live in the megalithic chambered tombs of the period which were supposed to have been equipped with stone doors. (One would scarcely be surprised to read further that the doors often jammed, thus exlpaining the skeletons frequently found inside!) Even 70 years ago British archaeology had advanced far beyond that; presumably Lockyer had never entered a museum and seen a stone axe. Memories of this kind of thing still help to perpetuate a divide between workers like the Thoms and many orthodox archaeologists.

These historical insights are very useful but the chapters on the astronomy of the ancient Babylonians and of the American Indian civilisations are too brief to be of more than casual interest. Presumably the section on ley lines and 'geomancy' was included as another warning about the eccentric ideas that still flourish on the fringes of megalithic astronomy and which also help to keep many archaeologists at a distance. Perhaps this very breadth of coverage conceals another danger. The author often gives guidance and opinions on the present state of our knowledge of Neolithic Western Europe but these are based primarily on the technical archaeoastronomical evidence, itself only a small fragment of the total knowledge we have of the period concerned.
For example, there is not one but two vitally important aspects of hypotheses about the 'masterminds' among the megalith builders. The first of course concerns the plausibility of the sites claimed as observatories, or as showing high meterological skill in measuring, and has been discussed extensively many times: this book deals mainly with it. However, the question of what kind of social organisation the people concerned had is an equally important but much trickier subject; it is rarely touched on by archaeoastronomers and their followers as it depends mainly on more onthodox archaeological evidence as well as on anthropological knowledge. There is no problem in ancient Egypt and Babylonia, or in Mesoamerica, which were urban societies known to have had specialist classes of priests and wise men, but what about Neolithic Europe? The population there was in a pre-urban stage and the usual view is that it was much more simply organised, not stratified into classes, and that it certainly did not possess élite orders of astronomer-priests and wise men of the kind which should have existed even if only half of what Professor Thom claims is correct.

The problem is whether the most important Neolithic sites and artefacts can be reinterpreted in terms of such a stratified, theocratic society. If none can, then the case for sophisticated ancient astronomy becomes much harder to maintain, no matter how impressive the technical evidence. The reviewer recently devoted half of an entire book (Science and Society in Prehistoric Britain, 1977) to raising this problem, and to making a start on resolving it, but feels he still has some way to go before convincing all his colleagues. Mr Lancaster Brown, however, only brings up the problem in a few lines in the final chapter, saying simply that we can be sure that such an élite class existed and that "Archaeological field evidence strongly supports this idea". Neither the book cited, nor Aubrey Burl's fundamental work The Stone Circles of the British Isles (1976) is mentioned anywhere and one must regretfully conclude that this is a further example of the idea that it is enough to be familiar mainly with the specialised archaeoastronomical evidence. Yet that is only the start of the journey, providing a new and clear window on to the past in addition to many older ones, by means of which our very complex but fragmentary picture of life in Neolithic Britain and Europe may eventually be substantially modified.

Euan W. MacKie is Assistant Keeper in Archaeology and Anthropology at the Hunterian Museum, University of Glasgow, $U K$. 